\title{
LeRoy Johnson at McGee Bend Reservoir (Lake Sam Rayburn) in 1956
}

Edward B. Jelks

Follow this and additional works at: https://scholarworks.sfasu.edu/ita

Part of the American Material Culture Commons, Archaeological Anthropology Commons, Environmental Studies Commons, Other American Studies Commons, Other Arts and Humanities Commons, Other History of Art, Architecture, and Archaeology Commons, and the United States History Commons

Tell us how this article helped you.

This Article is brought to you for free and open access by the Center for Regional Heritage Research at SFA ScholarWorks. It has been accepted for inclusion in Index of Texas Archaeology: Open Access Gray Literature from the Lone Star State by an authorized editor of SFA ScholarWorks. For more information, please contact cdsscholarworks@sfasu.edu. 
LeRoy Johnson at McGee Bend Reservoir (Lake Sam Rayburn) in 1956

Creative Commons License

(c) $)(1)$ (9)

This work is licensed under a Creative Commons Attribution-NonCommercial 4.0 International License 


\title{
LeRoy Johnson at McGee Bend Reservoir (Lake Sam Rayburn) in 1956
}

\author{
Edward B. Jelks
}

McGee Bend was one of some 40 reservoir and dam projects in Texas where salvage archaeological excavations were carried out as part of the nationwide River Basin Surveys program administered by the Smithsonian Institution and the National Park Service between 1947 and 1968 (see Jelks 1965, 2006, 2014, 2017). In 1956, I rented an old vacant farmhouse for our McGee Bend field headquarters where our crew lived without indoor plumbing, and it was there that the photo of LeRoy Johnson bathing in a washtub was taken by one of our crew, Milburn Lathan (Figure 1).

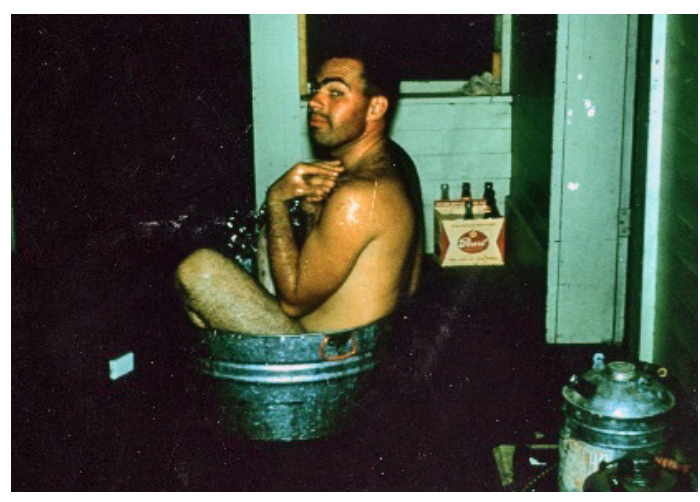

LeRoy heard the camera shutter snap, looked up, saw Milburn with camera in hand, and leapt out of the tub with mayhem on his mind. Skinny Milburn, who weighed perhaps 60 percent as much as the husky LeRoy, quite sensibly fled out the door into the adjoining piney woods at full speed with an enraged, naked, barefooted, soaking wet LeRoy in hot pursuit. Fortunately, after his bare feet had trod on a few of the pine cones that littered the ground, LeRoy gave up the chase. When Milburn returned warily the next morning, LeRoy had cooled down and let Milburn go without corporal punishment after I promised to give him the negative when I got the roll of film developed (I could not give him the whole roll as it contained some shots of excavated features and the like). Later, I did give LeRoy the negative, but only after secretly salting away a print.

\section{References Cited}

Jelks, E. B.

1965 The Archeology of McGee Bend Reservoir, Texas. Ph.D. dissertation, Department of Anthropology, The University of Texas at Austin.

2006 Reminiscences of Archaeology in Texas: 1947-1968. Plains Anthropologist 51(200):597-614.

2014 Archaeological Salvage at Texas Reservoir Construction Projects: 1945-1969. In Dam Projects and the Growth of American Archaeology: The River Basin Surveys and the Interagency Archeological Salvage Program, edited by K. M. Banks and J. Czaplicki, pp. 85-94. Left Coast Press, Inc., Walnut Creek.

2017 The Archaeology of Sam Rayburn Reservoir. CRHR Research Reports, Vol. 3. Center for Regional Heritage Research, Stephen F. Austin State University, Nacogdoches. 